を視察し, その後, 㞜殺し, 血液所見, 葴器重量等を各 群の間で比較した。各群の 1 日平均摂取水量には，著る しい差異はなかった。步もなる結果は，つぎの如くであ る。

1) $\mathrm{Cd}$ 単独投与群の体重増加は抑制されるが， $\mathrm{Zn}$ はこの抑制を阻止するよらな動らきを示さなかった。

2）Ｃd投与によって生ずる貧血，とくにへモグロビ ンの減少，ヘマトクリット値の低下を，Znはわずかに 阻止する傾向が認められた。

3） Cd のみを投与した群の単位体重当りの睪丸重量 は，大となるが， Zn 混合投与群も同様に大となり，臓 器重量の上からは，睪丸に站しても，Zn らいていないと思われる。

\section{8. $\mathrm{Cd}$ と Zn との生体内交換に関する実験}

館 正知，棠田昭吾，大沢一郎

(岐阜医大公衛)

$\mathrm{Cd}$ 大量投与以よる睪丸の退行変性が，Zn によって 阻止できる，という Parizek の報告から，Cd と Zn との生体内での競合および転换が考学られ, Cotzias は，とれを実証し得る寒験に成功している。

放射性 $\mathrm{Cd}$ の屎尿中への排泄状況之，放射性 $\mathrm{Cd}$ と 同時に非放射性の $\mathrm{Zn}$ を与えた場合, 及び放射性 $\mathrm{Cd}$ を与えた後，一定の期間を経てから，非放射性の $\mathrm{Zn}$ 与えた場合の，康尿中の放射能を比較することによって， 上記の競合，及び転換の仮説を検討できる。

また，体内に蓄積された $\mathrm{Cd}$ が，新らしく与えられた $\mathrm{Cd}$ と比較的容易に扣き変る。という Friberg の実験 がある。この追試を上記の実験と同時に行なった。

家鬼13頭を4群に分け， I群には $\mathrm{Cd}^{115}$ を体重 $\mathrm{kg}$ 当り約 26 万 $\mathrm{cpm}$, キャりナ一として $\mathrm{Cd}\left(\mathrm{NO}_{3}\right)_{2}$ を体 重 $\mathrm{kg}$ 当り $0.25 \mathrm{mg}$ 静脈内に注射し, 屎尿中の放射能を 2 日おきた26日間，シソチンーションカウンターで测 った。

他の 1 群は, $10^{-3} \mathrm{M}-\mathrm{Zn}\left(\mathrm{NO}_{3}\right)_{2}$ を, 体重 $\mathrm{kg}$ 当り $1 \mathrm{cc}$ （約 $0.2 \mathrm{mg} / \mathrm{kg}$ に相当）を，Cd $\mathrm{d}^{115}$ と同時に静脈内に注 射し，他の 1 群には，C ${ }^{115}$ の注射後 7 日目に与觉た。 また他の 1 群には，Cd ${ }^{115}$ の注射後7日目に, 非放射性 の $10^{-3} \mathrm{M}-\mathrm{Cd}\left(\mathrm{ZO}_{3}\right)_{2}$ 体重 $\mathrm{kg}$ 当り $1 \mathrm{cc}$ を静脈内に注 射した。いずれも2 日拈きに屎尿中の放射能を測定し， 上記の対照群と比較した。

この寒験条件では，はじね述べた仮説を確実に実証 するに足る成績が得られなかったし，また Fribergの 意見をららづけるに足る成績も得られなかった。 $\operatorname{cd}$ の屎㽷中への分配, 藏器中の含量などでは, 從来 の報告とほぼ同じ成績を得た。

\section{7． Cd の睪丸に及ぼす影響（第 2 報） $\mathrm{Zn}$ による Cd 障害の防護について}

森川幸雄, 石沢正一, 倉恒匡德 (九大公衛) 演者らは，体重 $\mathrm{g}$ 当り $1 \sim 2 \gamma$ のきわめて微量の $\mathrm{C}$ a が，マウスの罣丸の著明なる変化を就よぼすことを，昨 年，本学会に出いて報告した。今回は， $\mathrm{Zn}$ が Cd に﨎 して，拮抗的に作用するデータを得たので報告する。

実験動物：生後 4 5 力月，体重 28３2g のCF\#1 系マウスを使用した。

実験方法: $\mathrm{Cd} \mathrm{Cl}_{2}, \mathrm{Zn}\left(\mathrm{CH}_{3} \mathrm{CO}_{2}\right)_{2}, \mathrm{Cd} \mathrm{NO}_{3}, \mathrm{Zn}-$ $\mathrm{NO}_{3}$ 老下記 の如く混合して，A，B, C, D, E, F 液と乙 た。即ち， A, B, C, D 液は生理的食塩水 $100 \mathrm{cc}$ に対し て, $\mathrm{Cd} \mathrm{Cl}_{2} 50 \mathrm{mg}$ を含むが， $\mathrm{Zn}\left(\mathrm{CH}_{3} \mathrm{CO}_{2}\right)_{2}$ をそれ ぞれ $1 \mathrm{~g}, 0.25 \mathrm{~g}, 0.125 \mathrm{~g}, 0 \mathrm{~g}$ と減量してある。E.F 液では, 生理的食塩水 $100 \mathrm{cc}$ に各々 $75 \mathrm{mg}$ の $\mathrm{Cd} \mathrm{NO}_{3}$ を含毛が， E液では $\mathrm{Zn} \mathrm{NO}_{3}$ が加えてあり， $\mathrm{F}$ 液には 全然入っていない。マウス体重 $\mathrm{g}$ 当り $\mathrm{Cd}$ 的 $2 r$ の投与 量となるように，それぞれの液約 $0.2 \mathrm{cc}$ をマウスの背部 皮下に注射した。注射後 1 週より 3 力月後に屠殺して， 㖕丸を病理組織学的に検索した。使用した動物数は各液 に対して 5 匹から10匹であった。(表省略)

実験結果：1. $\mathrm{Cd} \mathrm{Cl}_{2} 50 \mathrm{mg} に \mathrm{Zn}\left(\mathrm{CH}_{3} \mathrm{CO}_{2}\right)_{2} 1$ $\mathrm{g}$ を混合したA群マウスの罣丸重量执よび肉眼的顕微鏡 的所見は，正常マウスの睪丸所見と 3 力月後に至るも変 らない。2. $\mathrm{Cd} \mathrm{NO}_{3} 75 \mathrm{mg} に Z \mathrm{Zn} \mathrm{NO}_{3} \quad 1.5 \mathrm{~g}$ を混合 したE群マウスでも，上記 1 と同様の結果を得た。 $\mathrm{Zn}$ イオンは $\mathrm{Cd}$ の睪丸傷害作用に対して，拮抗的に作用す るものと思わ机る。 $3 . \mathrm{Cd} \mathrm{Cl}_{2}, \mathrm{Cd} \mathrm{NO}_{3}$ は, 同じよら に，睪丸に対して破壊作用を持つ。これは，Cdイオン によると考えられる。4.Cystein, Vitamin K, Vitamin P, Vitamin E は, Cd の睪丸破壞作用を防徉: する效果は無いよらである。

418.コバルトカルボニール中毒に関する実験的研究

（第 I 報）

山崎茂䬦，杉本 年（三重県大塩浜病院高安内科） 最近，化学工業の発達にともない，コバルトカルボ二 一ルを触媒として使用されることが多くなっている。

実際には，コバルトカルボニールを溶媒トルエンにる かして使用されているので，コバルト量 $0.03116 \mathrm{~g} / \mathrm{cc}$ 含有の, コバルトカルボニール・トルエン液 $0.1 \mathrm{cc} を 。$ 
マウス（雑系 $20 \mathrm{gr}$ 前後, 雄) の腹腔内に注入し, 岡本 の原法汇従って組織染色を行ないコバルトの組織への 分布状態を検余した。

肝ではコバルトは血管周囲に見られ，心臟では心房に， とくに脂肪組織に多く見られた。肺では血管の基底膜に コバルトを染色し，腎では尿細管の基底膜並びに血管周 辺部に, 副腎では梿質内に認めた。脾では静脈洞, 脳で も静脈洞に多くのコバルトを認めた。

なお，腹腔内臓器周因脂肪組織の壞死並び飞各臓器組 儎の壞死も見られたが，これは，コバルトカルボニール のためのみとは断定できなかった。

\section{9. 銅の毒性に関する研究（第 2 報〉}

\section{豊川行平，黑子武道（東大衛生）}

銅長期の投与の生体に怙よぼす影響に関しては，現在 までのところ，諸家の意見は必らずしも一致していな い。 Mallory は, 家鬼酶酸銅を長期投与して, 肝蔵 に壊死・再生から，さらに肝硬変にいたる変化を認めた が，これらの結果を否定する研究者も少なくない。演者 らは，これらの点を再検討するために，まずその基璴実 験として, 経口投与された銅の蔵器内に郝ける経時变化

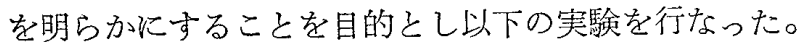

実験動物として，マウスを用いた。1 群 4〜8匹とし たマウス10群に，酶酸銅の形で放射性銅（Cu-64）を経 口投与し，一定時間ごとに 1 群ずつを殺し，各臟器内の 銅量を測定した。

臓器内の銅量は, 臓器の種類により, 多少の差はある が, $2 \sim 4$ 時間で最高に達し, 以後, 急速に減少してい く。臟器のなかでは肝臓内の銅量は圧倒的に多く,また 他の蔵器にくらべて, 比較的長く保持される。脳住つい ては，ほとんどその沈着は認められなかった。

な和，あらかじめ10日間経口的洒酶酸銅を投与した 1 群のマウスに放射性銅を投与し，12時間後に屠殺して， 臓器内銅を測定したが，その量は，対照群とほとえぞ同 ごであった。

\section{0。頭諼の微量元素について（第-3.報）}

\section{Fe. Cu. 及び Zn 含有量の年令別・性別变動}

石沢正一, 酒井 淳, 森川幸雄, 倉恒匡徳 （九大公衛）

毛髪は，生体内微量元素を，かなり大量に含有してお。 り，それらの1種の排泄器官と考えられる。しかし，毛 髮中の微量元素についての研究は，ほとんどなされてい ない。著者らは, 第31回日本衛生学会で, 頭髮中の重金
属の定量法を詳細に報告し，続いて第35回日本産業衛生 学会で, 頭髮中の $\mathrm{Fe}, \mathrm{Cu}$ 和よび $\mathrm{Zn}$ の含有量につい て発表した。しかし，例数が少なかったため，健康者の 正常值を推定するには，不充分であったので，さらに例 数を追加して，5〜80才の約 300 名の頭髮について，

Fe. $\mathrm{Cu}$ 和よび $\mathrm{Zn}$ 含有量を測定した成績を一括して報 告する。

1) 平均值: 男 175 名, 女 143 名, 単位は $\mu \mathrm{g} / \mathrm{g}$ とす る。

$\begin{array}{lllllll}\text { 男 } & \mathrm{Fe} & 15.4 & \mathrm{Cu} & 12.4 & \mathrm{Zn} & 141.9\end{array}$

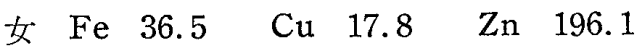

$\mathrm{Zn}$ 含有量は, $\mathrm{Fe}, \mathrm{Cu}$ にくらべて, 斨然多いことが 注目される。生体内の各臓器, 組織で, $Z \mathrm{n}$ が $\mathrm{Fe}$ より。 このように多いのは, 二, 三の臓器を除いては見られな いことである。

2) 性別：頭髪中の $\mathrm{Fe}, \mathrm{Cu}$ 预よび $\mathrm{Zn}$ 含有量は, 男より女が多い。とくに，Fe は女が男の約 2 倍に達し ている。Znも，女がはるかに男を灌駕している。

3 ) 年令別: $5 \sim 9$ 才では, $\mathrm{Fe}, \mathrm{Cu}$ および $\mathrm{Zn}$ 含有 量の性差は小さい。10１4才のころに，れれぞれの含有 量が最低值を示し，20才前後の成人では，增量している が，明らか性差が認められる。60才以後の老年では， $\mathrm{Zn}$ は依然として高值を示し, 男は $\mathrm{Fe}, \mathrm{Cu}$ の減少する 傾向がある。

4) 個体差:男は各年令群ともに標準徧差が 小さい が，女は大きい。とくに Fe 含有量の個体差は女ではき わめて大きい。老年期には男女とともに, $\mathrm{Fe}, \mathrm{Cu}, \mathrm{Zn}$ が著るしい高值を示寸例が多く見られるよらである。

421．金属坴予防対策よりみた低水素型被覆郕の膠結刋 にっいて

額田 桑（京都府立医大衛生）

明石信爾（三石酎火煉瓦）

著者らは，低水素棒による金属熱発生は，熔接時に $800^{\circ} \mathrm{C}$ 附近に加熱されると, 被覆剂中の水硝子が脆化し。 その結果，飛散する $\mathrm{MgO}$ 等の金属酸化物が飛散する以 前から吸着している $\mathrm{CO}, \mathrm{CO}_{2}$ とともに生体に吸入さ机 るという仮説を実験的飞証明し，本学会に報告した。す た，以上の理論によると，被覆剤中に膠結剤として， $800^{\circ} \mathrm{C}$ 附近加収縮して，金属酸化物を封入する效果の あるものを使用すれば，金属熱発生の防止に役立つこと も，本学会ですでに指摘した。今回は，某鉱山のa）普 通口ウ石， b ）珪化口ウ石， c ） 口ウ石粘土， d ）特殊 処理した粘土の 4 種について，前回之同様，熱膨脤，熱 